\title{
Epigenetic silencing of SMOC1 in traditional serrated adenoma and colorectal cancer
}

\author{
Hironori Aoki ${ }^{1, *}$, Eiichiro Yamamoto ${ }^{1,2, *}$, Akira Takasawa ${ }^{3}$, Takeshi Niinuma ${ }^{1}$, Hiro-0 \\ Yamano ${ }^{2}$, Taku Harada ${ }^{1}$, Hiro-O Matsushita ${ }^{4}$, Kenjiro Yoshikawa ${ }^{4}$, Ryo Takagi ${ }^{4}$ Eiji \\ Harada ${ }^{4}$, Yoshihito Tanaka4, Yuko Yoshida4, Tomoyuki Aoyama ${ }^{3}$, Makoto Eizuka5, \\ Akira Yorozu ${ }^{1}$, Hiroshi Kitajima ${ }^{1}$, Masahiro Kai ${ }^{1}$, Norimasa Sawada ${ }^{3}$, Tamotsu \\ Sugai ${ }^{5}$, Hiroshi Nakase ${ }^{2}$ and Hiromu Suzuki ${ }^{1}$ \\ ${ }^{1}$ Department of Molecular Biology, Sapporo Medical University School of Medicine, Sapporo, Japan \\ ${ }^{2}$ Department of Gastroenterology and Hepatology, Sapporo Medical University School of Medicine, Sapporo, Japan \\ ${ }^{3}$ Department of Pathology, Sapporo Medical University School of Medicine, Sapporo, Japan \\ ${ }^{4}$ Department of Digestive Disease Center, Akita Red Cross Hospital, Akita, Japan \\ ${ }^{5}$ Department of Molecular Diagnostic Pathology, School of Medicine, Iwate Medical University, Morioka, Japan \\ "These authors contributed equally to this work \\ Correspondence to: Hiromu Suzuki, email: hsuzuki@sapmed.ac.jp \\ Keywords: SMOC 1; colorectal cancer; traditional serrated adenoma; DNA methylation; CIMP \\ Received: June 26, $2017 \quad$ Accepted: November 30, $2017 \quad$ Published: December 20, 2017 \\ Copyright: Aoki et al. This is an open-access article distributed under the terms of the Creative Commons Attribution License 3.0 \\ (CC BY 3.0), which permits unrestricted use, distribution, and reproduction in any medium, provided the original author and source \\ are credited.
}

\section{ABSTRACT}

Colorectal sessile serrated adenoma/polyps (SSA/Ps) are well-known precursors of colorectal cancer (CRC) characterized by BRAF mutation and microsatellite instability. By contrast, the molecular characteristics of traditional serrated adenoma (TSAs) are not fully understood. We analyzed genome-wide DNA methylation in TSAs having both protruding and flat components. We identified 11 genes, including SMOC1, methylation of which progressively increased during the development of TSAs. SMOC1 was prevalently methylated in TSAs, but was rarely methylated in SSA/Ps $(p<0.001)$. RT-PCR and immunohistochemistry revealed that SMOC1 was expressed in normal colon and SSA/Ps, but its expression was decreased in TSAs. Ectopic expression of SMOC1 suppressed proliferation, colony formation and in vivo tumor formation by CRC cells. Analysis of colorectal lesions $(n=847)$ revealed that SMOC1 is frequently methylated in TSAs, high-grade adenomas and CRCs. Among these, SMOC1 methylation was strongly associated with KRAS mutation and CpG island methylator phenotype (CIMP)-low. These results demonstrate that epigenetic silencing of SMOC1 is associated with TSA development but is rarely observed in SSA/Ps. SMOC1 expression could thus be a diagnostic marker of serrated lesions, and SMOC1 methylation could play a role in neoplastic pathways in TSAs and conventional adenomas.

\section{INTRODUCTION}

Colorectal cancer (CRC) is one of the most commonly diagnosed malignancies and a leading cause of cancer mortality. Appropriate screening and removal of premalignant lesions at high risk to develop $\mathrm{CRC}$ is essential for reducing the incidence and mortality of CRC. Identification of the molecular alterations that occur at the premalignant step would improve our understanding of the tumorigenesis mechanism and could lead to the development of new strategies for CRC prevention.

CRCs are thought to arise from adenomas through accumulation of multiple genetic alterations, including mutation of APC, KRAS and TP53. In addition to the adenoma-carcinoma sequence, the serrated neoplastic pathway is now recognized to be an alternative pathway of 
CRC development [1, 2]. Serrated lesions (serrated polyps) are largely subdivided into hyperplastic polyps (HPs), sessile serrated adenoma/polyps (SSA/Ps) and traditional serrated adenomas (TSAs), and the evidence now indicates that SSA/Ps and TSAs are important premalignant lesions. [3] It is well documented that SSA/Ps are precursors of sporadic CRCs with $B R A F$ mutation, microsatellite instability (MSI) and concurrent hypermethylation of multiple loci, which is termed as $\mathrm{CpG}$ island methylator phenotype (CIMP) [2, 4-7]. TSAs are thought to be precursors of microsatellite stable (MSS) CRCs [8], but the molecular mechanisms underlying the development and progression of TSAs are not yet fully understood.

TSAs exhibit distinct genetic and epigenetic characteristics. For instance, recent studies showed that PTPRK-RSPO3 fusion and RNF43 mutations are characteristic features of TSAs [9, 10], although another study reported that RNF43 mutations are observed in both SSA/Ps and TSAs [11]. SSA/Ps are tightly associated with $B R A F$ mutation, while TSAs mostly harbor $B R A F$ or $K R A S$ mutations $[8,12]$. TSAs with $B R A F$ mutation exhibit features similar to $\mathrm{SSA} / \mathrm{Ps}$, including proximal colon location and CIMP-high. However, they rarely exhibit $M L H 1$ methylation, and they retain MLH1 protein expression [8]. The frequency of CIMP-high is lower in $K R A S$ mutant and $K R A S / B R A F$ wild-type TSAs, but approximately half of these lesions exhibit CIMP-low [8]. Another study also showed that TSAs are characterized by distal colon location, less frequent $B R A F$ mutation and smaller numbers of methylated genes than SSA/Ps [13]. Taken together with recent observations that both $K R A S$ and $B R A F$ mutations can induce CIMP $[14,15]$, these results suggest that aberrant DNA methylation is an important driver of the serrated neoplastic pathway, though genes with aberrant methylation likely differ between SSA/Ps and TSAs.

Analysis of gene expression signatures in a large cohort of colon cancers suggested that this disease can be subcategorized into three molecular subtypes: colon cancer subtype 1 (CCS1) and CCS2 are associated with chromosomal instability and MSI, respectively, while CCS3 is characterized by an unfavorable prognosis and is thought to develop though the serrated neoplastic pathway [16]. It is uncertain whether CCS3 tumors originate from TSAs, but the lack of MSI and the relative abundance of $B R A F / K R A S$ mutations and CIMP in this category suggests TSAs have the potential to develop aggressive CRCs. Thus, clarification of the underlying molecular alterations in TSAs may lead to development of useful biomarkers and new strategies for CRC prevention.

In earlier studies, we showed that analysis in lesions consisting of premalignant and more advanced components within the same tumors is a useful strategy for unraveling the molecular evolution during colorectal tumorigenesis [5, 7]. In the present study, we aimed to use that approach to clarify the molecular events that occur during TSA development.
We identified a series of genes, including SMOC1, as targets of aberrant DNA methylation in TSAs and found that SMOC1 methylation may be associated with the development and malignant progression of TSAs.

\section{RESULTS}

\section{Methylation of SMOC1 is acquired during the development of TSAs}

TSAs with protruding forms are often accompanied by flat components within the same tumors. The flat components are histologically similar to HPs and SSA/Ps, and are considered to be precursors of protruding TSAs (Figure 1A) [12, 17-19]. To identify changes in the DNA methylation that occur during the development of TSAs, we carried out Infinium HumanMethylation 450 BeadChip (HM450) analysis with a series of TSAs $(n=4)$ that contained both protruding and flat components. To identify DNA methylation specifically associated with TSA development, we also analyzed a set of SSA/P specimens $(n=3)$ using HM450. We first compared the methylation status between the protruding and flat components of the TSAs, and identified a series of $2486 \mathrm{CpG}$ sites at which methylation levels were significantly higher in the protruding portions $(p<0.05, \mid \Delta \beta$-value $\mid>0.1$, Figure $1 \mathrm{~B}$, Supplementary Figure $1 \mathrm{~A})$. We then compared the methylation status of the selected $2456 \mathrm{CpG}$ sites between the protruding TSAs and SSA/Ps, and identified a set of $230 \mathrm{CpG}$ sites that were predominantly methylated in TSAs (Figure 1B, Supplementary Figure 1B).

Unsupervised clustering analysis using the selected $230 \mathrm{CpG}$ sites revealed that they could be subcategorized into 2 clusters (Figure 1C). In the first cluster, we noted that methylation levels were elevated throughout the entire series of selected $\mathrm{CpG}$ sites in the protruding TSAs, whereas elevated methylation in the second cluster was more specific to the protruding TSAs (Figure 1C). Among the $\mathrm{CpGs}$ in cluster 2, examination of those located within $\mathrm{CpG}$ islands in gene promoters revealed that $30 \mathrm{CpGs}$ were associated with the promoters of 11 genes, B3GALNT1, CADPS, CCDC180, FAM92A1, FEZ1, FRMD4B, GABRA4, OGFRL1, PRDM16, SMOC1 and $Z N F 345$. We next used bisulfite pyrosequencing to analyze the methylation status of these genes in additional clinical specimens that included normal colonic tissue $(n=$ $61)$, HPs $(n=52)$, SSA/Ps $(n=107)$ and TSAs $(n=47)$. We found that the $\mathrm{CpG}$ island in SMOC1 (SPARC-related modular calcium binding 1) was specifically methylated in TSAs (Figure 1D, 1E). Methylation of the remaining 10 genes was also elevated in TSAs, but the methylation was not specific to TSAs or was much less frequent than in SMOC1 (Supplementary Figure 2). Moreover, bisulfite sequencing analysis in TSAs with protruding and flat components within the same tumors again revealed increased SMOC1 methylation in the protruding 
components (Figure 1F). These results suggest methylation of SMOC1 is associated with the development of TSAs.

\section{Methylation of SMOC1 is associated with gene silencing}

To clarify whether SMOC1 methylation is associated with its silencing, we analyzed the methylation and expression status of SMOC1 in a series of CRC cell lines and samples of normal colonic tissue. Elevated SMOC1 methylation was detected in 10 of the $12 \mathrm{CRC}$ cell lines tested, whereas SMOC1 was unmethylated in normal colonic tissue (Figure 2A, upper panel). Bisulfite sequencing analysis in selected CRC cell lines confirmed that the $\mathrm{CpG}$ island in SMOC1 was densely hypermethylated in these cells (Figure 2B). Quantitative reverse-transcription PCR (qRT-PCR) analysis showed that levels of SMOC1 expression were significantly decreased in all CRC cell lines tested, as compared to normal colonic tissue (Figure 2A, lower panel). Among the CRC cells, Colo320 and T84 cells exhibited only minimal levels of SMOC1 methylation, and Colo320
A

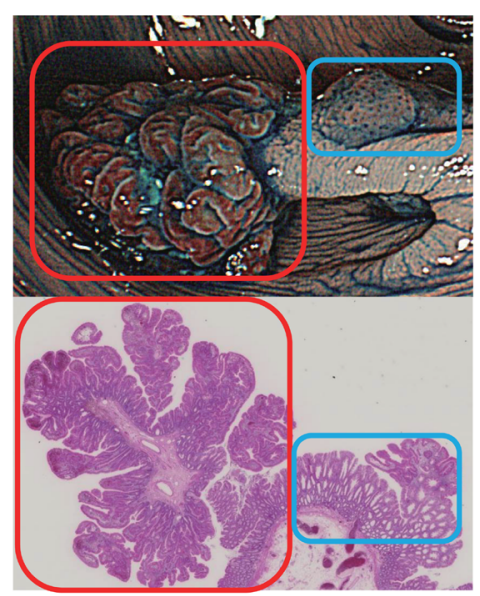

D

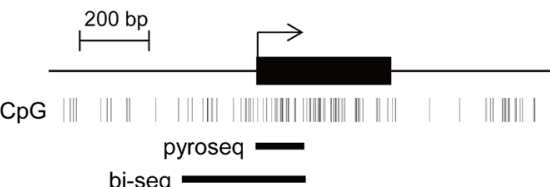

E

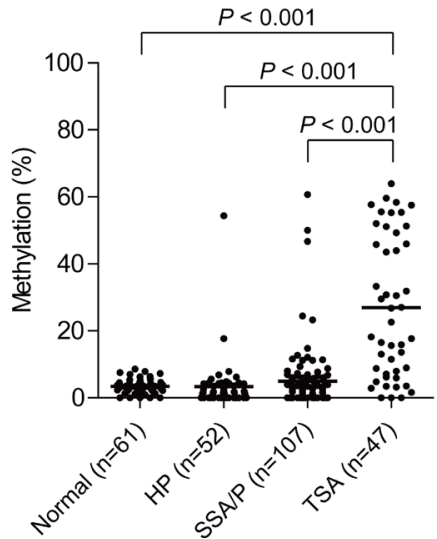

B

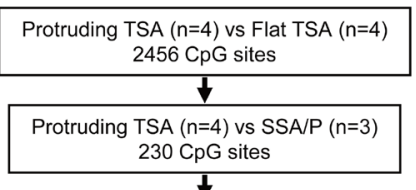

Hierarchical clustering analysis $123 \mathrm{CpG}$ sites ( 79 genes)

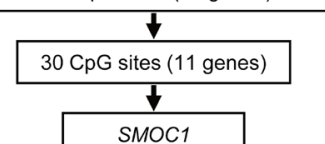

C Cluster 1 Cluster

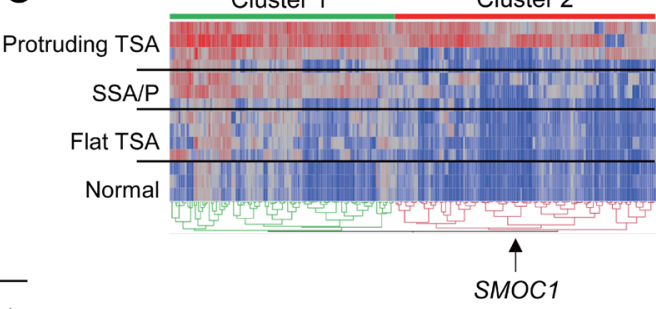

$\mathbf{F}$

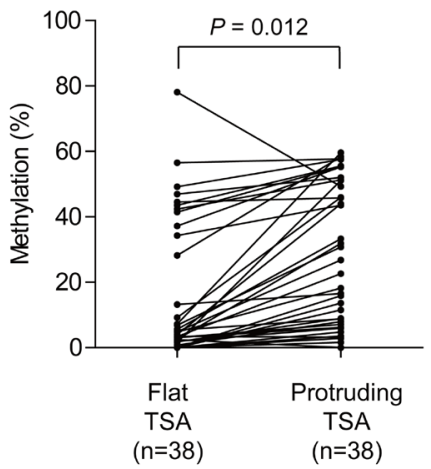

Figure 1: Identification of DNA methylation associated with the development of TSAs. (A) Representative example of TSA. An endoscopic view is shown on the top and a histological view is below. Red boxes indicate a protruding component and blue boxes indicate a flat component. (B) Workflow to identify DNA methylation in TSAs. (C) Heatmap of the selected $230 \mathrm{CpG}$ sites within the protruding components of TSAs $(n=4)$, SSA/Ps $(n=3)$, flat components of TSAs $(n=4)$ and normal colonic tissue $(n=3)$. Clusters 1 and 2 include 107 and $123 \mathrm{CpG}$ sites, respectively. (D) Diagram of the promoter region of SMOC1. The transcription start site and exon 1 are shown on the top, and the regions analyzed using bisulfite pyrosequencing and bisulfite sequencing are shown below. (E) Summarized results of bisulfite pyrosequencing of SMOC1 in specimens from the indicated lesions and adjacent normal colonic tissues. (F) Results of bisulfite pyrosequencing of SMOC1 in specimens from TSAs consisting of protruding and flat components. 
showed the highest SMOC1 expression among the CRC cell lines tested (Figure 2A). Moreover, SMOC1 expression in multiple $\mathrm{CRC}$ cell lines was increased by the DNA methyltransferase inhibitor 5-aza-2'-deoxycytidine (5-aza-dC, $2 \mu \mathrm{M}$ for $72 \mathrm{~h}$ ) (Figure $2 \mathrm{C}$ ). These results suggest SMOC1 is epigenetically silenced in association with $\mathrm{CpG}$ island hypermethylation in nearly all of the CRC cell lines tested, though it may be inactivated by a different mechanism in T84 cells.
We next performed bisulfite pyrosequencing and qRT-PCR of SMOC1 in clinical specimens that included normal colonic tissues, SSA/Ps and TSAs. Elevated methylation and decreased expression of SMOC1 were detected in TSA specimens, whereas SMOC1 was unmethylated and expressed in both normal colonic tissue and SSA/Ps (Figure 2D). Bisulfite sequencing revealed that the majority of $\mathrm{CpG}$ sites are unmethylated in normal colonic tissue (Figure 2E). By contrast, a TSA specimen

\section{A}
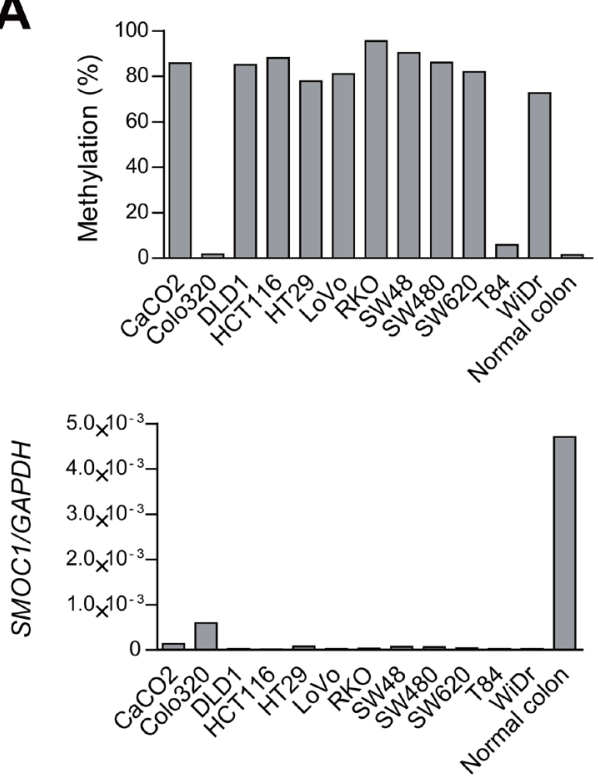

D
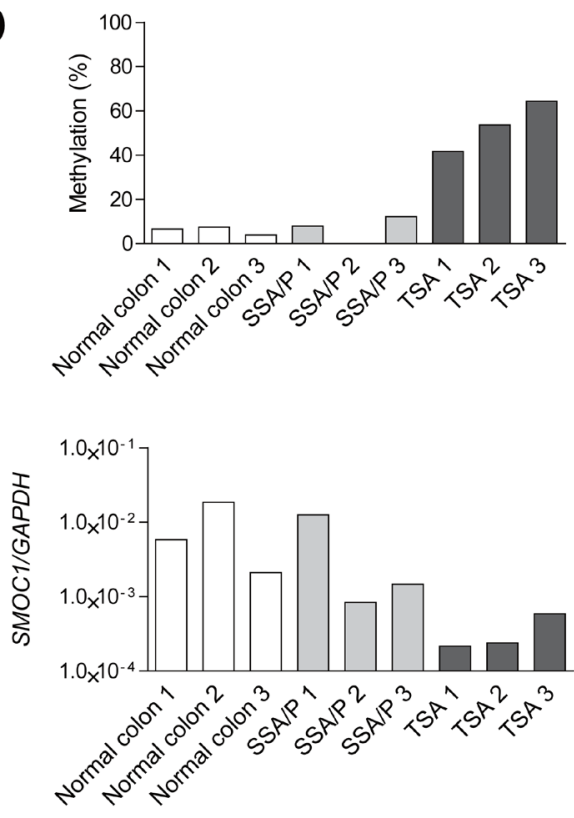

\section{B RKO}
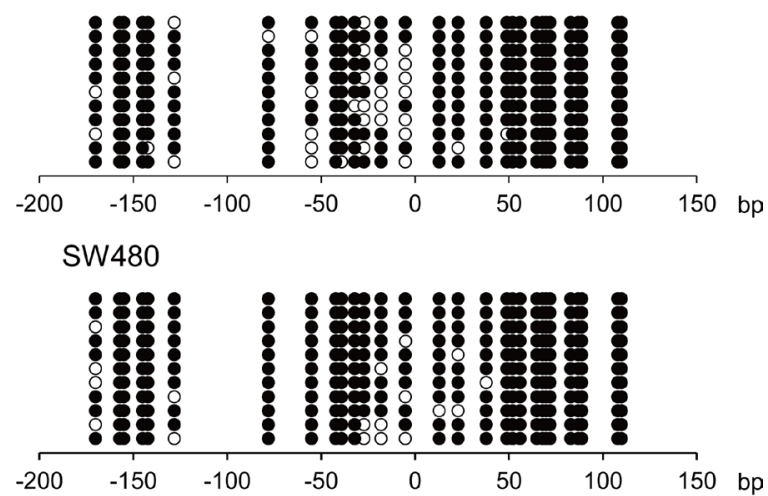

C

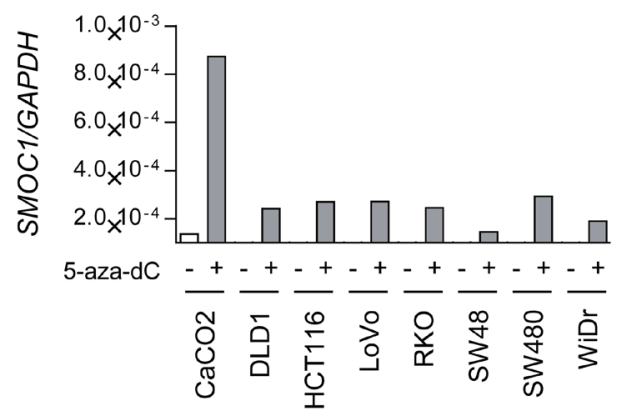

E
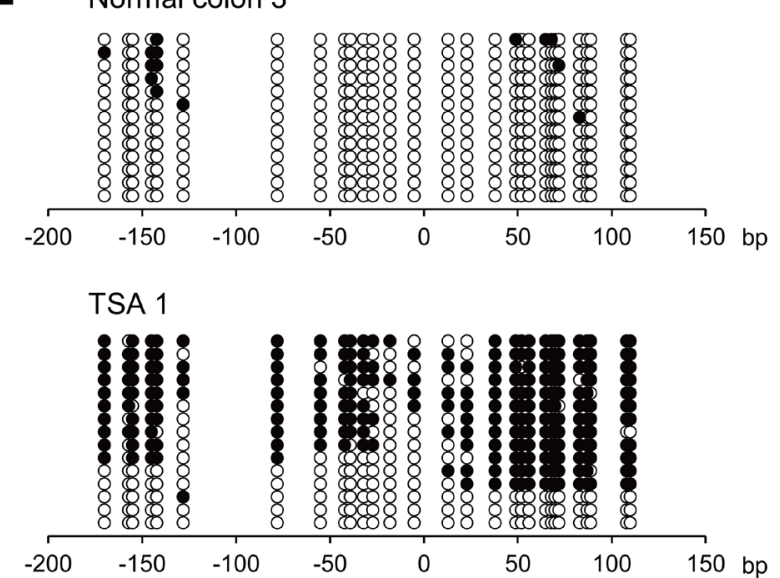

Figure 2: Analysis of SMOC1 methylation and expression in colorectal tumors. (A) Bisulfite pyrosequencing (top) and qRT-PCR (bottom) analyses of SMOC1 in the indicated CRC cell lines and normal colonic tissue. (B) Bisulfite sequencing analysis of the SMOC1 CpG island in the indicated CRC cell lines. Open and filled circles represent unmethylated and methylated CpG sites, respectively. (C) qRT-PCR analysis of SMOC1 in the indicated CRC cell lines, with or without 5-aza-dC treatment. (D) Bisulfite pyrosequencing (top) and qRT-PCR (bottom) analyses of SMOC1 in normal colonic tissues and primary serrated lesions. (E) Bisulfite sequencing analysis of $S M O C 1$ in the representative samples in (D). 
showed a mixture of methylated and unmethylated alleles, probably reflecting a mixture of tumor and normal cells (Figure 2E). These results suggest SMOC1 methylation is associated with its transcriptional silencing in TSAs.

We also evaluated SMOC1 expression in a TSA specimen with both flat and protruding components. Immunohistochemical analysis revealed SMOC1 expression to be lower in the protruding component than in the flat portion or adjacent normal mucosa (Figure 3A). Moreover, expression of Ki-67 was increased somewhat in the protruding component, suggesting loss of SMOC1 may be associated with increased cell proliferation (Figure 3B). In specimens of TSA $(n=11), \operatorname{SSA} / \mathrm{P}(n=12)$ and adjacent normal colonic mucosa $(n=23)$, SMOC1 was expressed in the epithelium of normal colonic tissue and SSA/Ps, but SMOC1 expression was significantly reduced in a large number of TSAs (Figure 3C). Quantification using a scoring system revealed that there was little or no SMOC1 expression in the majority of TSA specimens tested (Figure 3D). These results indicate that SMOC1 may be a useful marker to discriminate between SSA/Ps and TSAs.

\section{Functional analysis of SMOC1 in CRC}

To investigate the function of SMOC1 in colorectal tumors, we transfected CRC cells with a SMOC1
A

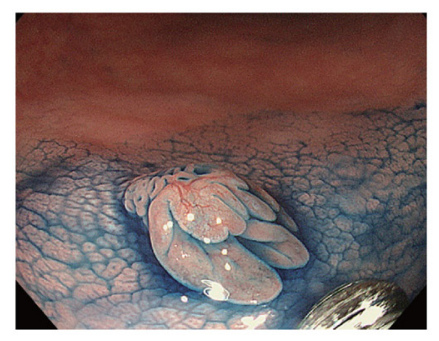

B
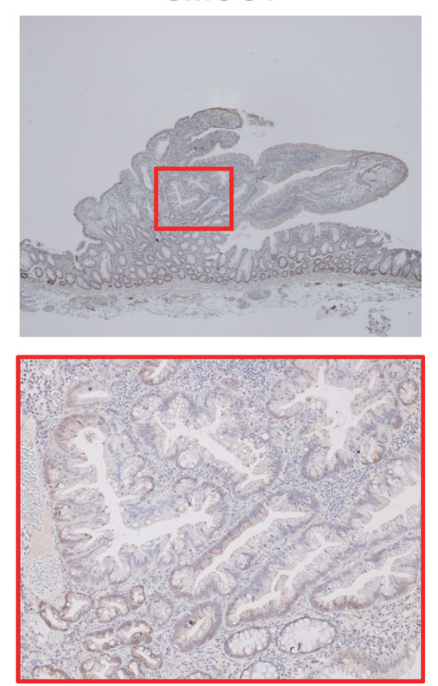

Ki-67
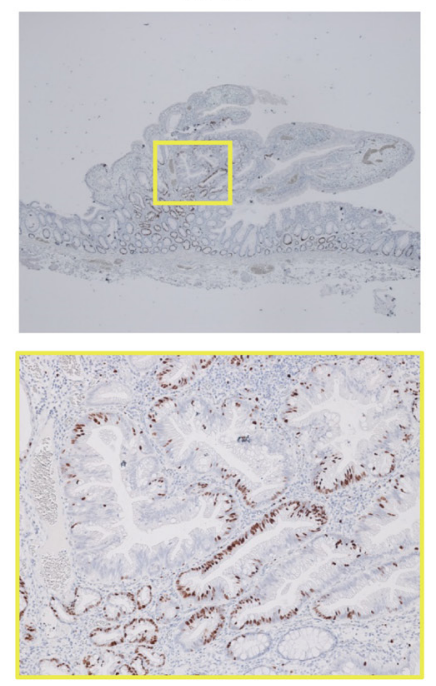

C

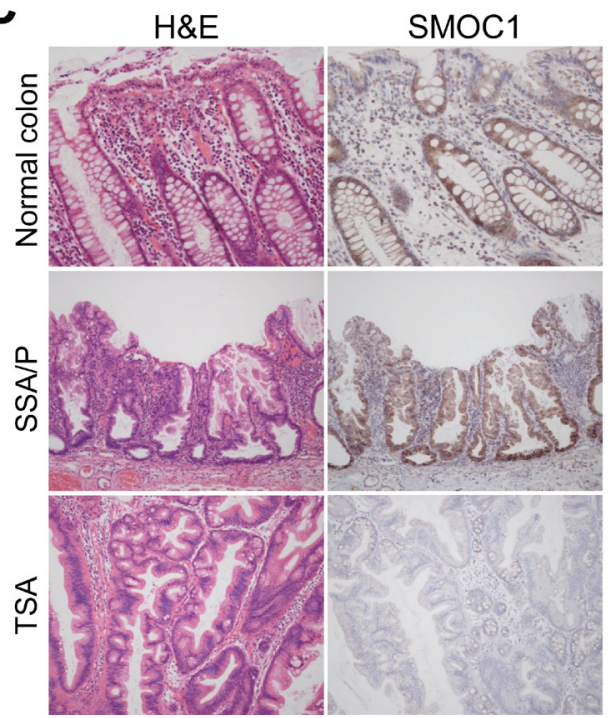

D

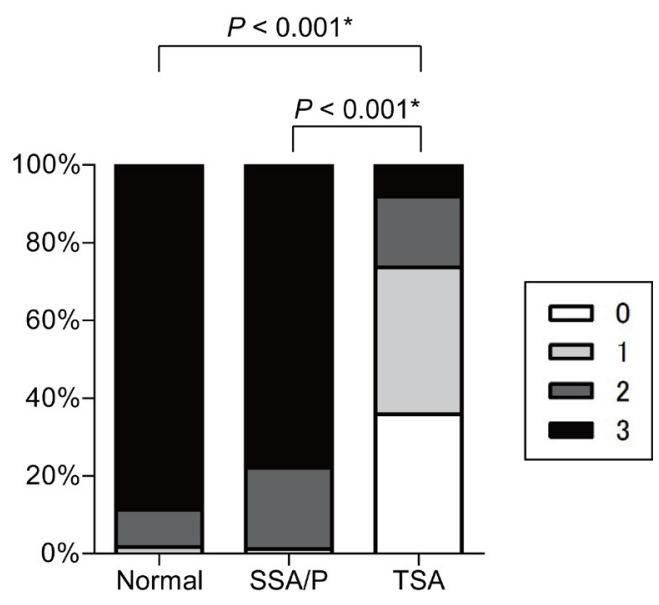

Figure 3: Immunohistochemical analysis of SMOC1 in serrated lesions. (A) Endoscopic view of a TSA with protruding and flat components. (B) SMOC1 (left) and Ki-67 (right) staining in the TSA specimen shown in (A). Magnified views indicated by red and yellow boxes are shown below. (C) Representative views of hematoxylin and eosin (left) and SMOC1 (right) staining in normal colonic tissue, SSA/P and TSA specimens. (D) Summarized results for SMOC1 expression levels in normal colon $(n=23)$, SSA/Ps $(n=12)$ and TSAs $(n=11)$. 'Fisher's exact test. 
expression vector or empty vector and confirmed the protein expression with western blotting (Figure 4A). We then carried out colony formation assays and found that SMOC1 suppresses colony formation by RKO and SW480 cells (Figure 4B), and in cell viability assays ectopic SMOC1 expression suppressed CRC cell proliferation (Figure 4C). On the other hand, SMOC1 did not suppress CRC cell migration or invasion in migration and Matrigel invasion assays (Supplementary Figure 3A, 3B). Flow cytometric analysis showed that SMOC1 also did not induce apoptosis in CRC cells (Supplementary Figure 3C). In vivo, inoculation of SW480 cells transiently transfected with a SMOC1 expression vector or empty vector into nude mice revealed that SMOC1 moderately suppresses tumor formation (Figure 4D, Supplementary Figure 3D).

Finally, we examined the effect of SMOC1 depletion in cancer cells. Because all CRC cell lines only minimally expressed SMOC1, we analyzed SMOC1 expression in a series of gastric cancer (GC) cell lines. qRT-PCR analysis revealed decreased SMOC1 expression in the majority of GC cell lines, though not in MKN45 cells, which expressed SMOC1 at a level similar to that in normal gastric tissue (Supplementary Figure 4A). However, SMOC1 knockdown in MKN45 cells moderately promoted the cell proliferation (Supplementary Figure 4B, 4C). These results suggest $S M O C 1$ may act as a tumor suppressor.

\section{SMOC1 methylation is associated with progression of colorectal tumors}

To further clarify the role of SMOC1 methylation in the development of $\mathrm{CRC}$, we analyzed mixed colorectal lesions in which cancerous and TSA components were present together in the same tumors (Supplementary Figure 5A). The TSA components within these lesions were considered to be CRC precursors that might contain
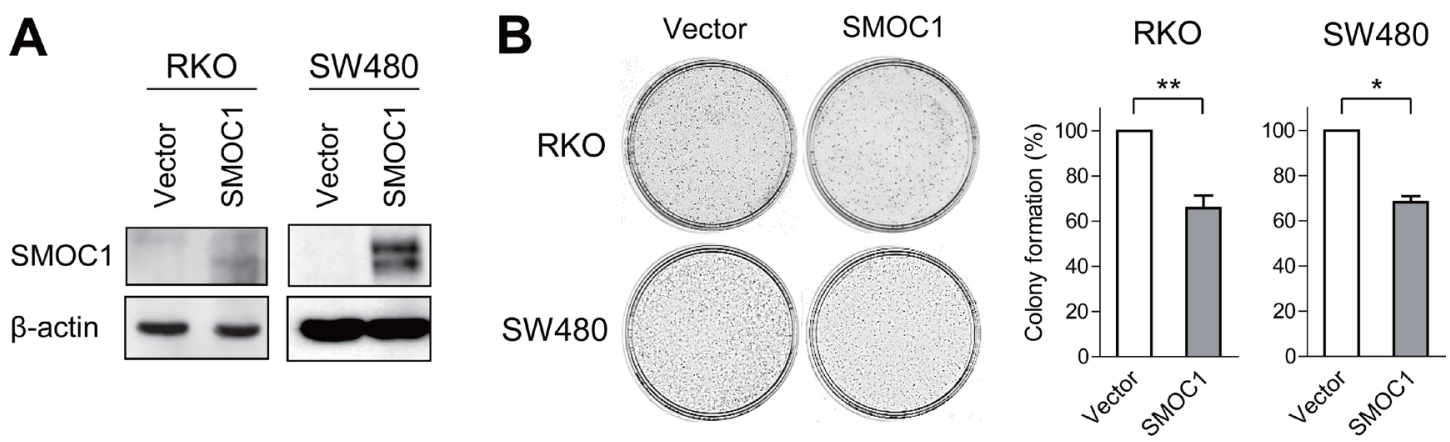

C

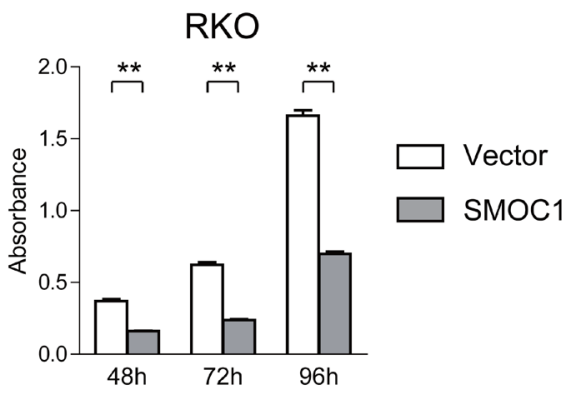

D
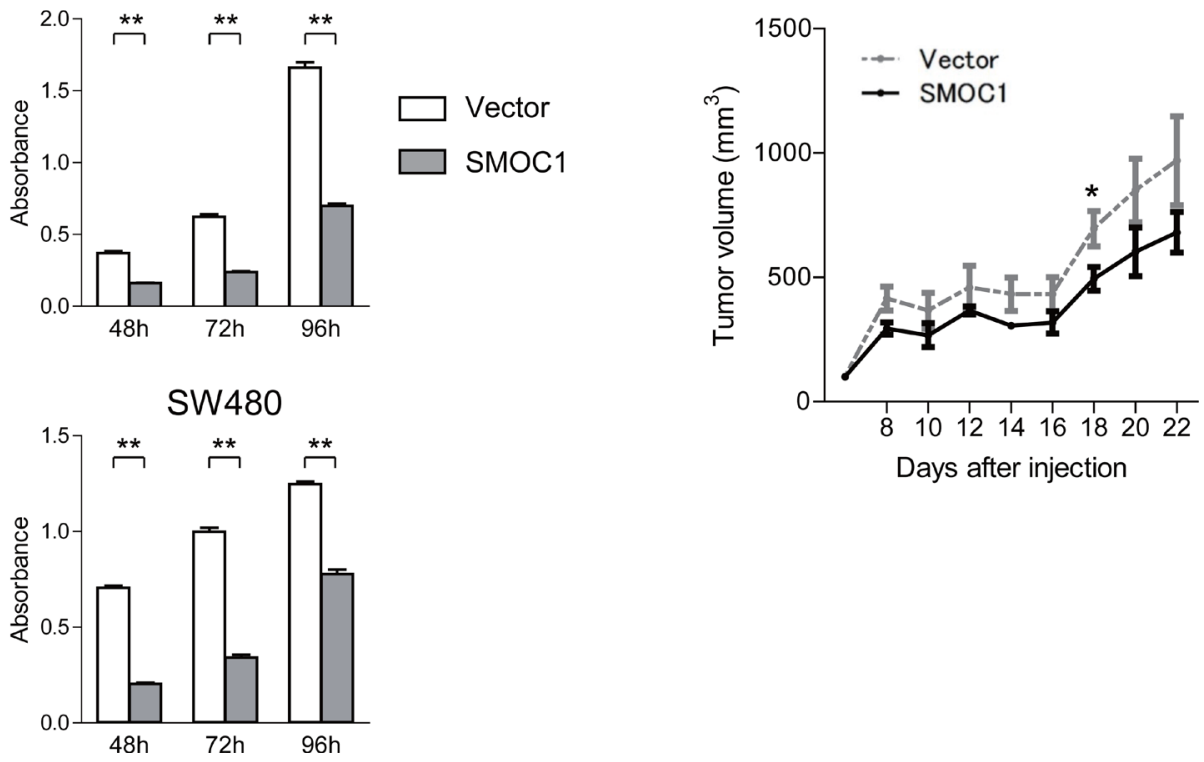

Figure 4: Functional analysis of SMOC1 in CRC cells. (A) Western blot analysis of SMOC1 in the indicated CRC cells transfected with a SMOC1 expression vector or a control vector (Vector). (B) Colony formation assays using the indicated CRC cell lines transfected with the indicated vectors. Representative results are on the left, and relative colony formation efficiencies are on the right. Shown are means of 3 replications; error bars represent SDs. ${ }^{*} P<0.05,{ }^{* *} P<0.01$. (C) Cell viability assays using the indicated CRC cell lines transfected with the indicated vectors. Shown are means of 8 replications; error bars represent SDs. ${ }^{* *} P<0.01$. (D) Tumor growth in mice injected with SW480 cells transfected with the indicated vectors. Shown are means of 5 replications; error bars represent SDs. ${ }^{*} P<0.05$. 
molecular alterations that promote malignant progression. We found that levels of SMOC1 methylation were higher in TSAs associated with cancer than in those without cancer, suggesting SMOC1 methylation may be a marker identifying TSAs at high risk of developing CRC (data not shown). We therefore generated a receiver operating characteristic (ROC) curve to assess the ability of SMOC1 methylation levels to distinguish pure TSAs from TSAs with cancer and found the most discriminating cutoff value to be $36 \%$ (sensitivity, 75\%; specificity, 66\%) (Supplementary Figure 5B). By comparing the expression and methylation of SMOC1 in representative clinical specimens, we confirmed that methylation levels higher than $36 \%$ were associated with decreased expression (Supplementary Figure 5C, 5D).

We also examined the association between SMOC1 methylation and the clinicopathological features in a large cohort of patients with non-invasive colorectal tumors $(n=473)$. We then categorized the tumors according to their SMOC1 methylation levels using the cutoff value calculated above, and found that elevated SMOC1 methylation ( $\geq 36 \%)$ was associated with older age and larger tumor sizes, whereas it was not associated with gender, tumor location or tumor morphology (Table 1). We also found that SMOC1 methylation was frequently elevated in colorectal adenomas and cancers. Notably, high SMOC1 methylation was more prevalent in high-grade adenomas than low-grade adenomas
(Table 1). The higher SMOC1 methylation was associated with KRAS mutation, wild-type BRAF, TP53 mutation and CIMP-low (Table 1). When we analyzed a series of invasive colorectal tumors $(n=374)$, we again found that elevated SMOC1 methylation was associated with KRAS mutation and CIMP-low (Table 2). SMOC1 methylation was also associated with older age and proximal colon location, but it was not associated with gender, tumor morphology, TMN category or lymphatic or vascular invasion (Table 2).

The results summarized above suggest that $S M O C 1$ methylation is associated with malignant progression of colorectal tumors, including TSAs and conventional adenomas. To test that possibility, we analyzed a series of colorectal lesions in which premalignant components were present together with cancerous components within the same tumors. As described above, SMOC1 was methylated in most specimens of TSA with cancer (Figure 5). It is noteworthy that a majority of the cancer components exhibited CIMP-low, and none of the tumors showed MLH1 methylation (Figure 5). Among the adenoma specimens with cancer $(n=23)$, elevated SMOC1 methylation was found in 6 adenomas and 10 samples of cancer tissue (Figure 5). SMOC1 methylationpositive adenomas and cancers were associated with frequent $K R A S$ mutation and a lack of $M L H 1$ methylation. By contrast, the vast majority of SSA/Ps with cancer exhibited $B R A F$ mutation and CIMP-high, while SMOC1
TSA with cancer $(n=8)$

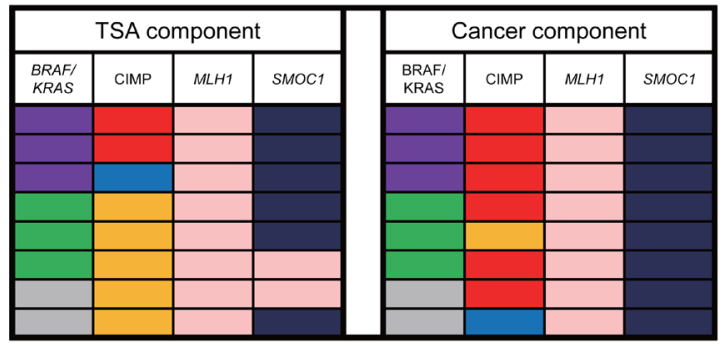

SSA/P with cancer $(n=14)$

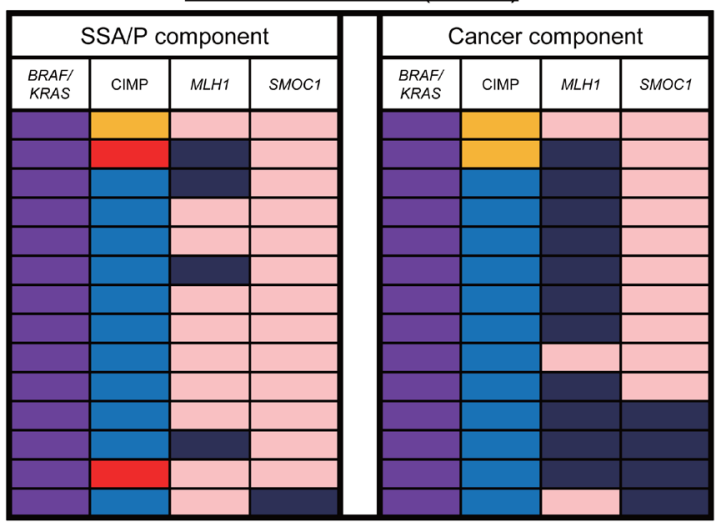

Adenoma with cancer $(n=23)$

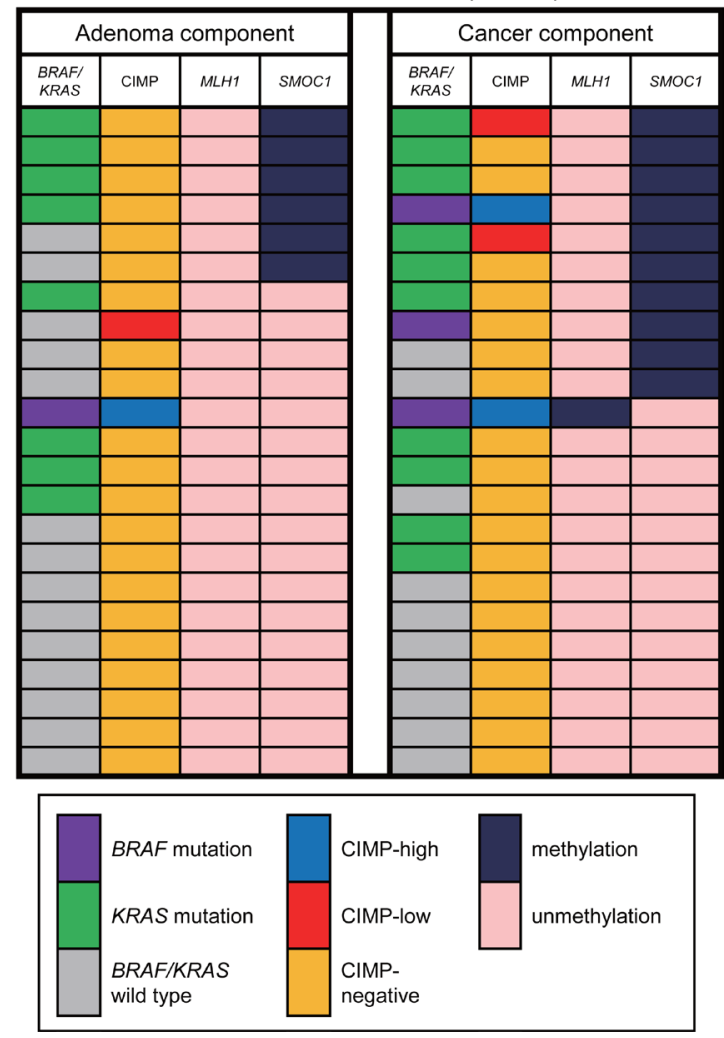

Figure 5: Changes in the molecular alterations during the progression of colorectal tumors. Summary of the molecular features in colorectal tumors consisting of premalignant and malignant components are shown. 
Table 1: Correlation between SMOC1 methylation and the clinicopathological features of non-invasive colorectal tumors

\begin{tabular}{|c|c|c|c|}
\hline & \multicolumn{2}{|c|}{ SMOC1 methylation } & \multirow[b]{2}{*}{$P$} \\
\hline & $<36 \%(n=376)$ & $\geq 36 \%(n=97)$ & \\
\hline Age $(y$, mean \pm SD $)$ & $64.0 \pm 11.1$ & $68.6 \pm 11.2$ & $<0.001$ \\
\hline \multicolumn{4}{|l|}{ Gender } \\
\hline Female & 112 & 31 & NS \\
\hline Male & 264 & 66 & \\
\hline \multicolumn{4}{|l|}{ Location } \\
\hline Proximal & 186 & 50 & NS \\
\hline Distal & 190 & 47 & \\
\hline Size $(m m$, mean \pm SD) & $10.6 \pm 6.8$ & $18.1 \pm 13.0$ & $<0.001$ \\
\hline \multicolumn{4}{|l|}{ Morphology } \\
\hline Depressed & 2 & 1 & NS \\
\hline Flat & 192 & 63 & \\
\hline Flat plus protruding & 14 & 9 & \\
\hline Protruding & 136 & 58 & \\
\hline \multicolumn{4}{|l|}{ Histology } \\
\hline $\mathrm{HP}$ & 51 & 1 & $<0.001$ \\
\hline $\mathrm{SSA} / \mathrm{P}$ & 104 & 3 & \\
\hline $\mathrm{SSA} / \mathrm{P}+\mathrm{CD}$ & 23 & 3 & \\
\hline $\mathrm{SSA} / \mathrm{P}+$ cancer & 11 & 3 & \\
\hline TSA & 31 & 16 & \\
\hline $\mathrm{TSA}+$ cancer & 0 & 8 & \\
\hline Low-grade adenoma & 64 & 10 & \\
\hline High-grade adenoma & 53 & 32 & \\
\hline Cancer & 39 & 21 & \\
\hline \multicolumn{4}{|l|}{$B R A F$} \\
\hline Mut & 151 & 19 & $<0.001$ \\
\hline WT & 225 & 78 & \\
\hline \multicolumn{4}{|l|}{$K R A S$} \\
\hline Mut & 74 & 50 & $<0.001$ \\
\hline WT & 302 & 47 & \\
\hline \multicolumn{4}{|l|}{ TP53 } \\
\hline Mut & 26 & 14 & 0.018 \\
\hline WT & 350 & 83 & \\
\hline \multicolumn{4}{|l|}{ CIMP status } \\
\hline Negative & 248 & 57 & 0.010 \\
\hline Low & 50 & 25 & \\
\hline High & 78 & 15 & \\
\hline \multicolumn{4}{|l|}{ MLH1 methylation } \\
\hline Methylated & 18 & 2 & NS \\
\hline Unmethylated & 358 & 95 & \\
\hline
\end{tabular}

NS, not significant; CD, cytological dysplasia; Mut, mutated; WT, wild type. 
Table 2: Correlation between SMOC1 methylation and the clinicopathological features of invasive colorectal tumors SMOC1 methylation

\begin{tabular}{|c|c|c|c|}
\hline & $<36 \%(n=235)$ & $\geq 36 \%(n=139)$ & $P$ \\
\hline $\operatorname{Age}(y$, mean $\pm S D)$ & $66.3 \pm 12.2$ & $70.6 \pm 10.6$ & $<0.001$ \\
\hline \multicolumn{4}{|l|}{ Gender } \\
\hline Female & 84 & 64 & NS \\
\hline Male & 151 & 75 & \\
\hline \multicolumn{4}{|l|}{ Location } \\
\hline Proximal & 86 & 71 & 0.006 \\
\hline Distal & 149 & 68 & \\
\hline \multicolumn{4}{|l|}{ Morphology } \\
\hline Type 0 & 44 & 18 & NS \\
\hline Depressed & 30 & 8 & \\
\hline Flat & 7 & 7 & \\
\hline Flat plus protruding & 0 & 0 & \\
\hline Protruding & 7 & 3 & \\
\hline Type 1 & 21 & 17 & \\
\hline Type 2 & 151 & 102 & \\
\hline Type 3 & 10 & 2 & \\
\hline Type 4 & 0 & 0 & \\
\hline Type 5 & 9 & 0 & \\
\hline \multicolumn{4}{|l|}{$B R A F$} \\
\hline Mut & 19 & 4 & NS \\
\hline WT & 216 & 135 & \\
\hline \multicolumn{4}{|l|}{$K R A S$} \\
\hline Mut & 48 & 72 & $<0.001$ \\
\hline WT & 187 & 67 & \\
\hline \multicolumn{4}{|l|}{ TP53 } \\
\hline Mut & 56 & 31 & NS \\
\hline WT & 179 & 108 & \\
\hline \multicolumn{4}{|l|}{ CIMP status } \\
\hline Negative & 200 & 88 & $<0.001$ \\
\hline Low & 24 & 38 & \\
\hline High & 11 & 13 & \\
\hline \multicolumn{4}{|l|}{ MLH1 methylation } \\
\hline Methylated & 13 & 2 & NS \\
\hline Unmethylated & 222 & 137 & \\
\hline \multicolumn{4}{|l|}{ pT category } \\
\hline pT1 & 33 & 14 & NS \\
\hline pT2 & 32 & 28 & \\
\hline pT3 & 125 & 81 & \\
\hline pT4 & 25 & 9 & \\
\hline NA & 20 & 7 & \\
\hline \multicolumn{4}{|l|}{ pN category } \\
\hline pN0 & 140 & 83 & NS \\
\hline
\end{tabular}




\begin{tabular}{lccc} 
pN1 & 47 & 35 & \\
pN2 & 22 & 13 & \\
NA & 26 & 8 & NS \\
pM category & & 120 & \\
pM0 & 184 & 15 & NS \\
pM1 & 31 & 4 & \\
NA & 20 & 40 & \\
Lymphatic invasion & & 85 & NS \\
Negative & 59 & 14 & \\
Positive & 140 & & \\
NA & 36 & 58 & 67 \\
Vascular invasion & 85 & 14 & \\
Negative & 113 & 37 & \\
Positive & & & \\
NA & NA, & & \\
\hline
\end{tabular}

NS, not significant; Mut, mutated; WT, wild type; NA, not available.

methylation was infrequent in both the SSA/P and cancer tissues (Figure 5). The frequency of MLH1 methylation progressively increased in the cancer tissues, which is consistent with our previous observations (Figure 5) [5, 7]. These results suggest that $S M O C 1$ methylation may play a key role in the development of TSAs and/or high-grade adenomas, which could eventually progress to CIMP-low or CIMP-negative CRCs.

\section{DISCUSSION}

To clarify the molecular mechanism underlying the development of TSAs, we screened for DNA methylation changes associated with morphological and histological progression within TSA lesions. The list of genes we identified in this study included multiple genes implicated in cancer. For instance, FEZ1 (also known as LZTS1) is a tumor suppressor gene located at $8 \mathrm{p} 22$, a region frequently deleted in human tumors [20]. FEZ1 is silenced in association with promoter methylation in various malignancies, including gastric and breast cancer [21, 22]. A DNA methylome analysis in acute myeloid leukemia (AML) identified methylation of 7 genes, including FAM92A1, that were predictive of outcome in AML [23]. PRDM16 (also known as MEL1) is overexpressed and associated with a poor prognosis in pediatric AML [24]. In addition, PRDM16 is hypomethylated and overexpressed in astrocytoma [25], whereas it is hypermethylated in lung and esophageal cancers [26, 27].

Among the genes identified, we noted that methylation of SMOC1 is highly specific to TSAs among serrated lesions. SMOC1 belongs to the SPARC (secreted protein acidic and rich in cysteine) family of matricellular proteins, which has 8 members: SPARC, SPARCL1/ Hevin, SPOCK1, -2, -3, SMOC1, -2 and FSTL1 [28].
Although the physiological function of SMOC1 is not fully understood, recent studies have shown that SMOC1 is associated with osteoblast differentiation, ocular and limb development and angiogenesis [29-31]. Members of the SPARC family have been implicated in various human malignancies. SPARC, for instance, is markedly overexpressed in pancreatic cancer, and its expression is associated with a poorer prognosis $[32,33]$. Conversely, $S P A R C$ is silenced by DNA hypermethylation in CRC, and its restoration using 5-aza-dC improves the response to chemotherapy [34]. Another study showed that exercise stimulates SPARC secretion from muscle tissues and that SPARC inhibits colon tumorigenesis [35]. These results suggest that SPARC may exert opposite effects during tumorigenesis in different tissues. In contrast to SPARC, FSTL1 was recently shown to inhibit pancreatic cancer growth [28]. SMOC2 is known as an intestinal stem cell gene, and its elevation is associated with an aggressive and invasive phenotype in CRC [36]. In contrast to the other family members, few studies have shown possible involvement of SMOC1 in cancer. Brellier et al. reported that SMOC1 interacts with tenacin-C, an extracellular matrix protein overexpressed in various cancers, and that SMOC1 expression is elevated in brain tumors [37]. Fackler et al. searched for DNA methylation associated with hormone receptor status in breast cancer and found that methylation of 40 genes, including $S M O C 1$, is associated with estrogen receptor status and disease progression [38]. However, the function of SMOC1 in breast cancer remains unknown, and SMOC1 methylation has not been reported in other tumor types.

We showed here that SMOCl methylation is associated with transcriptional silencing in both primary and cultured colorectal tumor cells. Notably, SMOC1 expression was significantly decreased in all CRC 
cell lines tested, and its ectopic expression suppressed proliferation of both CIMP-positive (RKO) and CIMPnegative (SW480) CRC cell lines. In addition to TSAs, SMOC1 was frequently methylated in high-grade adenomas and CRCs, suggesting SMOC1 may play a common tumor suppressor role during colorectal tumorigenesis. However, the function of SMOC1 remains largely unknown, and further study will be necessary to clarify the biological significance of SMOC1 methylation in colorectal tumors.

Histologically, TSAs often show a complex and distorted tubulovillous or villous configuration [39]. A recent study reported that serrated tubulovillous adenomas (sTVAs), which are a type of TVA, represent an important precursor of KRAS mutated, CIMP-low/negative and MSS CRCs [40]. In the present study, we noted that SMOC1 methylation is strongly associated with KRAS mutation and CIMP-low, while it is not positively associated with $B R A F$ mutation or MLH1 methylation. These results indicate that SMOC1 methylation may be associated with the development of KRAS mutant, CIMP-low and MSS CRCs derived from TSAs and sTVAs.

Our findings also demonstrated that immunohistochemical staining of SMOC1 is highly discriminative between TSAs and SSA/Ps, suggesting SMOC1 could serve as a diagnostic marker for TSAs. Pathological diagnosis of serrated lesions is often confused by the morphological similarities between categories and the heterogeneity within respective lesions $[17,18]$. A recent gene expression analysis in SSA/Ps and HPs identified ANXA10 as a potential marker of SSA/Ps [41]. The combination of SMOC1 and ANXA10 may provide improved diagnostic performance with serrated lesions, and further study is warranted.

In summary, we found that SMOC1 is preferentially methylated in TSAs. Epigenetic silencing of SMOC1 may be associated with the development of KRAS mutant, CIMP-low and MSS CRCs derived from TSAs or conventional adenomas. Our data also suggest that SMOC1 expression could serve as a diagnostic biomarker for serrated lesions, and that SMOC1 methylation may be a predictive marker of precursor lesions at high risk of developing aggressive CRCs.

\section{MATERIALS AND METHODS}

\section{Study population and cell lines}

Colorectal tissue specimens were collected from Japanese patients who underwent endoscopic or surgical resection at Akita Red Cross Hospital and Teine-Keijinkai Hospital. Biopsy specimens were endoscopically obtained from a total of 991 specimens from 473 noninvasive tumors, 374 invasive tumors and 61 samples of adjacent normal colonic tissue. We carefully observed the microsurface structures of tumors using magnifying endoscopes and obtained biopsy specimens from tumor surfaces, so that the differences in the tumor cell content among samples would be minimal. Informed consent was obtained from all patients before collection of the specimens. Approval of this study was obtained from Institutional Review Board of Akita Red Cross Hospital, Teine-Keijinkai Hospital and Sapporo Medical University. CRC cell lines (CaCO2, Colo320, DLD1, HCT116, HT29, LoVo, RKO, SW48, SW480, SW620, T84 and WiDr) and a gastric cancer cell line (MKN45) were obtained and cultured as described previously $[42,43]$. To restore epigenetically silenced genes, cells were treated with $2 \mu \mathrm{M}$ 5-aza-2'-deoxycytidine (5-aza-dC) (Sigma-Aldrich, St Louis, MO, USA) for $72 \mathrm{~h}$, replacing the drug and medium every $24 \mathrm{~h}$. Genomic DNA was extracted using the standard phenol-chloroform procedure. Total RNA was extracted using TRIZOL reagent (Thermo Fisher Scientific, Waltham, MA, USA) and then treated with a DNA-free kit (Thermo Fisher Scientific).

\section{Endoscopic and histological analysis}

Colorectal tumors were observed at high magnification using high-resolution magnifying endoscopes (CF-H260AZI; Olympus, Tokyo, Japan) after staining with indigo carmine dye and $0.05 \%$ crystal violet. Microsurface structures were classified according to Kudo's pit pattern classification system [44, 45]. Most often, one biopsy specimen was collected from each lesion for extracting genomic DNA. When more than two subcomponents were found in a single lesion, biopsy specimens were obtained for each portion, as described previously [5, 7]. The lesions were then treated through endoscopic mucosal resection, endoscopic submucosal dissection or surgical resection, after which histological analyses were carried out. Conventional adenomas were subcategorized into low-grade or high-grade adenomas. High-grade adenomas were defined as being $1 \mathrm{~cm}$ or more in diameter and/or with villous components and/or with high-grade dysplasia.

\section{Infinium assay}

Genome wide DNA methylation was analyzed using an Infinium HumanMethylation450 BeadChip (Illumina, San Diego, CA, USA) as described [46]. The data were then assembled using GenomeStudio methylation software (Illumina) and analyzed using Microsoft Excel (Microsoft Corporation, Redmond, WA, USA) and JMP 11 (SAS Institute Inc., Cary, NC, USA). Probes on the $\mathrm{X}$ and $\mathrm{Y}$ chromosomes were excluded from the analysis. The Gene Expression Omnibus accession number for the microarray data is GSE96540.

\section{Methylation analysis using bisulfite pyrosequencing and bisulfite sequencing}

Genomic DNA (1 $\mu \mathrm{g})$ was modified with sodium bisulfite using an EpiTect Bisulfite Kit (Qiagen, Hilden, Germany), after which bisulfite sequencing and 
pyrosequencing were carried out as described previously [7]. Using five methylation markers (MINT1, MINT2, MINT12, MINT31 and p16), tumors were defined as CIMPhigh (four or more loci showed methylation), CIMP-low (two or three loci showed methylation) or CIMP-negative (0 or one loci showed methylation). For bisulfite sequencing, amplified PCR products were cloned into pCR2.1-TOPO vector (Thermo Fisher Scientific), and 10 to 15 clones from each sample were sequenced using an ABI3130x automated sequencer (Thermo Fisher Scientific). Primer sequences and PCR product sizes are listed in Supplementary Table 1.

\section{Mutation analysis}

Mutations within codon 600 of $B R A F$ and codons 12 and 13 of $K R A S$ were examined by pyrosequencing using $B R A F$ and $K R A S$ pyro kits (Qiagen) according to the manufacturer's instructions. TP53 mutation was initially assessed using PCR-SSCP followed by direct sequencing, as described previously [7].

\section{Quantitative reverse-transcription PCR}

Single-stranded cDNA was prepared using SuperScript III reverse transcriptase (Thermo Fisher Scientific). Quantitative reverse-transcription PCR (qRT-PCR) was carried out using TaqMan Gene Expression Assays (SMOC1, Hs00951041_m1; GAPDH, Hs02758991_g1; Thermo Fisher Scientific) and a 7500 Fast Real-Time PCR System (Thermo Fisher Scientific). SDS ver. 1.4 (Thermo Fisher Scientific) was used for comparative delta $\mathrm{Ct}$ analysis.

\section{Immunohistochemistry}

Immunohistochemical staining was performed as described previously [47]. A rabbit anti-SMOC1 polyclonal antibody (1:1000 dilution, C-20; SigmaAldrich) and a mouse anti-Ki-67 monoclonal antibody (1:100 dilution, Clone MIB-1; BioGenex, Fremont, CA, USA) were used. The staining intensity of SMOC1 was assessed as strong (3), moderate (2), weak (1) or negative $(0)$. The proportions of positively stained tumor cells were recorded as 0 (no staining), 1 (1-10\%), $2(11-50 \%), 3(51-80 \%)$ or $4(81-100 \%)$. Because neoplasm heterogeneity caused varying degrees of immunoreactivity in the slides, we used an immunoreactive score (IRS) (e.g., intensity $3 \times$ proportion $4=$ immunoreactive score 12 , scale of 0 to 12) to improve accuracy [47-49]. All slides were independently evaluated by two pathologists (AT, TA) who were blinded to the clinical data.

\section{Expression vector and siRNA for SMOC1}

A full-length SMOC1 cDNA was amplified by PCR using cDNA derived from SMOC1-expressing MKN45 cells as a template and then cloned into pcDNA3.2/
V5/GW/D-TOPO (Thermo Fisher Scientific). Primer sequences are listed in Supplementary Table 1. For cell viability, migration, invasion, flow cytometry and xenograft assays, $1 \times 10^{6}$ cells were transfected with $1 \mu \mathrm{g}$ of control vector or SMOC1 expression vector using a Cell Line Nucleofector kit V (Lonza) with a Nucleofector I electroporation device (Lonza) as described [50]. For colony formation assays, $1 \times 10^{6}$ cells in 6 -well plates were transfected with $2.5 \mu \mathrm{g}$ of the vectors using Lipofectamine 3000 (Thermo Fisher Scientific). For RNA interference (RNAi)-mediated SMOC1 knockdown, $1 \times 10^{6}$ cells in 6-well plates were transfected with 25 pmol of a Silencer Select Pre-designed siRNA targeting SMOC1 (Thermo Fisher Scientific) or a negative control (Thermo Fisher Scientific) using Lipofectamine RNAiMAX (Thermo Fisher Scientific).

\section{Western blot analysis}

Western blot analysis was performed as described previously [50]. A mouse anti-V5 monoclonal antibody (1:5000 dilution, R960-25; Thermo Fisher Scientific) and a mouse anti- $\beta$-actin monoclonal antibody $(1: 10000$ dilution, clone AC-15; Sigma-Aldrich) were used.

\section{Colony formation assay}

Cells were transfected with plasmids as described above. After incubation for $24 \mathrm{~h}$, the transfectants were plated on $60-\mathrm{mm}$ culture dishes and selected for 10 to 14 days in $1.0 \mathrm{mg} / \mathrm{ml} \mathrm{G} 418$, after which colonies were stained with Giemsa.

\section{Cell viability assay}

Cells were transfected with plasmids or siRNAs as described above. The transfectants were seeded into 96-well plates to a density of $5 \times 10^{3}$ cells per well and incubated for $72 \mathrm{~h}$. Cell viability assays were then carried out using a Cell Counting kit-8 (Dojindo, Kumamoto, Japan) according to the manufacturer's instructions.

\section{Cell migration and invasion assay}

Cells were transfected with plasmids as described above. Transwell chambers were used for cell migration (BioCoat Control Insert 24-well plate $8.0 \mu \mathrm{m}$; Corning Inc., Corning, NY, USA) and invasion analyses (BioCoat Matrigel Invasion Chamber 24-well plate $8.0 \mu \mathrm{m}$; Corning Inc.). Cells were harvested $24 \mathrm{~h}$ after transfection and resuspended in culture medium containing $1 \mathrm{mg} / \mathrm{ml}$ bovine serum albumin, after which $1 \times 10^{5}$ cells were added to the upper chamber. Culture medium with $10 \%$ fetal bovine serum was added to the lower well. After incubation for $24 \mathrm{~h}$ at $37^{\circ} \mathrm{C}$, migrating or invading cells on the lower surface of the filter were fixed and stained using a DiffQuik staining kit (Sysmex, Tokyo, Japan). Cell numbers 
were determined microscopically by counting in five randomly selected fields per membrane.

\section{Flow cytometry}

Cells were transfected with the plasmids as described above. After incubation for $72 \mathrm{~h}$, apoptosis was measured using an ApoScreen Annexin V Apoptosis Kit (Southern Biotech, Birmingham, AL, USA). Briefly, $1 \times 10^{6}$ cells were washed twice in cold PBS and then resuspended in cold binding buffer, after which $10 \mu \mathrm{L}$ of Annexin V-FITC was added to $100 \mu \mathrm{L}$ of the cell suspension. The mixture was then incubated for $15 \mathrm{~min}$ on ice in the dark before addition of $380 \mu \mathrm{L}$ of cold binding buffer and $10 \mu \mathrm{L}$ of propidium iodide. For each sample, data were acquired from a minimum of $1 \times 10^{5}$ cells using a BD FACSCant II (BD Biosciences, Franklin Lakes, NJ, USA) with BD FACSDiva software (BD Biosciences), and were analyzed using FlowJo ver. 10 (FlowJo, LLC, Ashland, OR, USA).

\section{Xenograft studies}

Experiments were performed in accordance with the protocols approved by the institutional animal ethical committee at Sapporo Medical University. Mixtures of $1 \times 10^{6}$ SW480 cells transfected with control vector or SMOC1 expression vector and $0.2 \mathrm{ml}$ of Matrigel basement matrix (Corning Inc. Corning, NY, USA) were injected subcutaneously in the areas of the bilateral thighs of 6-weekold BALB/cAJcl-nu mice. Tumor size was measured every 2 days using digital calipers, and tumor volume was calculated using the formula length $\times$ width $^{2} / 2$. The experiment was repeated twice.

\section{Statistical analysis}

To compare differences in continuous variables between groups, $t$ tests or ANOVA with post hoc Tukey's tests were performed. Fisher's exact test or chi-squared test was used for analysis of categorical data. Values of $P<0.05$ (two-sided) were considered statistically significant. The minimum $P$-value method was used to determine the best cutoff value for the SMOC1 methylation level. Statistical analyses were carried out using GraphPad Prism ver. 5.0.2 (GraphPad Software, La Jolla, CA, USA).

\section{ACKNOWLEDGMENTS}

The authors thank Dr. William F. Goldman for editing the manuscript and Ms. Mutsumi Toyota and Ms. Tomo Hatahira for technical assistance.

\section{CONFLICTS OF INTEREST}

All authors declare no conflict of interest.

\section{FUNDING}

This study was supported in part by Grant-in-Aid for Scientific Research (C) from the Japan Society for Promotion of Science (JSPS KAKENHI 15K08973, E. Yamamoto), Grant-in-Aid for Scientific Research (B) from the Japan Society for Promotion of Science (JSPS KAKENHI 15H04299, H. Suzuki) and Grants-in-Aid for Young Investigators (B) from Japan Society for Promotion of Science (JSPS KAKENHI 15K18431, T. Harada; JSPS KAKENHI 15K19339, H. Aoki), JFE (The Japanese Foundation for Research and Promotion of Endoscopy) Grant (E. Yamamoto), The Takeda Science Foundation (E. Yamamoto).

\section{REFERENCES}

1. Fearon ER, Vogelstein B. A genetic model for colorectal tumorigenesis. Cell. 1990; 61:759-767.

2. Leggett B, Whitehall V. Role of the serrated pathway in colorectal cancer pathogenesis. Gastroenterology. 2010; 138:2088-2100.

3. Bosman FT, World Health Organization. International Agency for Research on Cancer. WHO classification of tumours of the digestive system. (Lyon: International Agency for Research on Cancer). 2010.

4. Spring KJ, Zhao ZZ, Karamatic R, Walsh MD, Whitehall VL, Pike T, Simms LA, Young J, James M, Montgomery GW, Appleyard M, Hewett D, Togashi K, et al. High prevalence of sessile serrated adenomas with BRAF mutations: a prospective study of patients undergoing colonoscopy. Gastroenterology. 2006; 131:1400-1407.

5. Kimura T, Yamamoto E, Yamano HO, Suzuki H, Kamimae S, Nojima M, Sawada T, Ashida M, Yoshikawa K, Takagi R, Kato R, Harada T, Suzuki R, et al. A novel pit pattern identifies the precursor of colorectal cancer derived from sessile serrated adenoma. Am J Gastroenterol. 2012; 107:460-469.

6. Ijspeert JE, Vermeulen L, Meijer GA Dekker E. Serrated neoplasia-role in colorectal carcinogenesis and clinical implications. Nat Rev Gastroenterol Hepatol. 2015; 12:401-409.

7. Yamamoto E, Suzuki H, Yamano HO, Maruyama R, Nojima M, Kamimae S, Sawada T, Ashida M, Yoshikawa K, Kimura T, Takagi R, Harada T, Suzuki R, et al. Molecular dissection of premalignant colorectal lesions reveals early onset of the $\mathrm{CpG}$ island methylator phenotype. Am J Pathol. 2012; 181:1847-1861.

8. Bettington ML, Walker NI, Rosty C, Brown IS, Clouston AD, McKeone DM, Pearson SA, Klein K, Leggett BA, Whitehall VL. A clinicopathological and molecular analysis of 200 traditional serrated adenomas. Mod Pathol. 2015; 28:414-427.

9. Sekine S, Yamashita S, Tanabe T, Hashimoto T, Yoshida H, Taniguchi H, Kojima M, Shinmura K, Saito Y, Hiraoka N, 
Ushijima T, Ochiai A. Frequent PTPRK-RSPO3 fusions and RNF43 mutations in colorectal traditional serrated adenoma. J Pathol. 2016; 239:133-138.

10. Tsai JH, Liau JY, Yuan CT, Lin YL, Tseng LH, Cheng ML, Jeng YM. RNF43 Is an Early and Specific Mutated Gene in the Serrated Pathway, With Increased Frequency in Traditional Serrated Adenoma and Its Associated Malignancy. Am J Surg Pathol. 2016; 40:1352-1359.

11. Yan HH, Lai JC, Ho SL, Leung WK, Law WL, Lee JF, Chan AK, Tsui WY, Chan AS, Lee BC, Yue SS, Man AH, Clevers H, et al. RNF43 germline and somatic mutation in serrated neoplasia pathway and its association with BRAF mutation. Gut. 2016.

12. Wiland HO 4th, Shadrach B, Allende D, Carver P, Goldblum JR, Liu X, Patil DT, Rybicki LA, Pai RK. Morphologic and molecular characterization of traditional serrated adenomas of the distal colon and rectum. Am J Surg Pathol. 2014; 38:1290-1297.

13. Sakai E, Fukuyo M, Ohata K, Matsusaka K, Doi N, Mano Y, Takane K, Abe H, Yagi K, Matsuhashi N, Fukushima J, Fukayama M, Akagi K, et al. Genetic and epigenetic aberrations occurring in colorectal tumors associated with serrated pathway. Int J Cancer. 2016; 138:1634-1644.

14. Serra RW, Fang M, Park SM, Hutchinson L, Green MR. A KRAS-directed transcriptional silencing pathway that mediates the $\mathrm{CpG}$ island methylator phenotype. Elife. 2014; 3:e02313.

15. Fang $M, O u J$, Hutchinson L, Green MR. The BRAF oncoprotein functions through the transcriptional repressor MAFG to mediate the $\mathrm{CpG}$ Island Methylator phenotype. Mol Cell. 2014; 55:904-915.

16. De Sousa EMF, Wang X, Jansen M, Fessler E, Trinh A, de Rooij LP, de Jong JH, de Boer OJ, van Leersum R, Bijlsma MF, Rodermond $\mathrm{H}$, van der Heijden M, van Noesel CJ, et al. Poor-prognosis colon cancer is defined by a molecularly distinct subtype and develops from serrated precursor lesions. Nat Med. 2013; 19:614-618.

17. Bettington ML, Chetty R. Traditional serrated adenoma: an update. Hum Pathol. 2015; 46:933-938.

18. Torlakovic EE, Gomez JD, Driman DK, Parfitt JR, Wang C, Benerjee T, Snover DC. Sessile serrated adenoma (SSA) vs. traditional serrated adenoma (TSA). Am J Surg Pathol. 2008; 32:21-29.

19. Kim KM, Lee EJ, Kim YH, Chang DK, Odze RD. KRAS mutations in traditional serrated adenomas from Korea herald an aggressive phenotype. Am J Surg Pathol. 2010; 34:667-675.

20. Ishii H, Vecchione A, Murakumo Y, Baldassarre G, Numata S, Trapasso F, Alder H, Baffa R, Croce CM. FEZ1/LZTS1 gene at 8 p22 suppresses cancer cell growth and regulates mitosis. Proc Natl Acad Sci U S A. 2001; 98:10374-10379.

21. Vecchione A, Ishii H, Shiao YH, Trapasso F, Rugge M, Tamburrino JF, Murakumo Y, Alder H, Croce CM, Baffa R.
Fez1/lzts1 alterations in gastric carcinoma. Clin Cancer Res. 2001; 7:1546-1552.

22. Chen L, Zhu Z, Sun X, Dong XY, Wei J, Gu F, Sun YL, Zhou J, Dong JT, Fu L. Down-regulation of tumor suppressor gene FEZ1/LZTS1 in breast carcinoma involves promoter methylation and associates with metastasis. Breast Cancer Res Treat. 2009; 116:471-478.

23. Marcucci G, Yan P, Maharry K, Frankhouser D, Nicolet D, Metzeler KH, Kohlschmidt J, Mrozek K, Wu YZ, Bucci D, Curfman JP, Whitman SP, Eisfeld AK, et al. Epigenetics meets genetics in acute myeloid leukemia: clinical impact of a novel seven-gene score. J Clin Oncol. 2014; 32:548-556.

24. Shiba N, Ohki K, Kobayashi T, Hara Y, Yamato G, Tanoshima R, Ichikawa H, Tomizawa D, Park MJ, Shimada A, Sotomatsu M, Arakawa H, Horibe K, et al. High PRDM16 expression identifies a prognostic subgroup of pediatric acute myeloid leukaemia correlated to FLT3ITD, KMT2A-PTD, and NUP98-NSD1: the results of the Japanese Paediatric Leukaemia/Lymphoma Study Group AML-05 trial. Br J Haematol. 2016; 172:581-591.

25. Lei H, Zou D, Li Z, Luo M, Dong L, Wang B, Yin H, Ma Y, Liu C, Wang F, Zhang J, Yu J, Li Y. MicroRNA-219-2-3p functions as a tumor suppressor in gastric cancer and is regulated by DNA methylation. PLoS One. 2013; 8:e60369.

26. Tan SX, Hu RC, Liu JJ, Tan YL, Liu WE. Methylation of PRDM2, PRDM5 and PRDM16 genes in lung cancer cells. Int J Clin Exp Pathol. 2014; 7:2305-2311.

27. Peng X, Xue H, Lü L, Shi P, Wang J, Wang J. Accumulated promoter methylation as a potential biomarker for esophageal cancer. Oncotarget. 2017; 8:679-691. http://doi. org/10.18632/oncotarget.13510.

28. Viloria K, Munasinghe A, Asher S, Bogyere R, Jones L, Hill NJ. A holistic approach to dissecting SPARC family protein complexity reveals FSTL-1 as an inhibitor of pancreatic cancer cell growth. Sci Rep. 2016; 6:37839.

29. Choi YA, Lim J, Kim KM, Acharya B, Cho JY, Bae YC, Shin HI, Kim SY, Park EK. Secretome analysis of human BMSCs and identification of SMOC1 as an important ECM protein in osteoblast differentiation. J Proteome Res. 2010; 9:2946-2956.

30. Okada I, Hamanoue H, Terada K, Tohma T, Megarbane A, Chouery E, Abou-Ghoch J, Jalkh N, Cogulu O, Ozkinay F, Horie K, Takeda J, Furuichi T, et al. SMOC1 is essential for ocular and limb development in humans and mice. Am J Hum Genet. 2011; 88:30-41.

31. Awwad K, Hu J, Shi L, Mangels N, Abdel Malik R, Zippel N, Fisslthaler B, Eble JA, Pfeilschifter J, Popp R, Fleming I. Role of secreted modular calcium-binding protein 1 (SMOC1) in transforming growth factor beta signalling and angiogenesis. Cardiovasc Res. 2015; 106:284-294.

32. Mantoni TS, Schendel RR, Rodel F, Niedobitek G, Al-Assar O, Masamune A, Brunner TB. Stromal SPARC 
expression and patient survival after chemoradiation for non-resectable pancreatic adenocarcinoma. Cancer Biol Ther. 2008; 7:1806-1815.

33. Guweidhi A, Kleeff J, Adwan H, Giese NA, Wente MN, Giese T, Buchler MW, Berger MR, Friess H. Osteonectin influences growth and invasion of pancreatic cancer cells. Ann Surg. 2005; 242:224-234.

34. Cheetham S, Tang MJ, Mesak F, Kennecke H, Owen D, Tai IT. SPARC promoter hypermethylation in colorectal cancers can be reversed by 5-Aza-2'deoxycytidine to increase SPARC expression and improve therapy response. Br J Cancer. 2008; 98:1810-1819.

35. Aoi W, Naito Y, Takagi T, Tanimura Y, Takanami Y, Kawai Y, Sakuma K, Hang LP, Mizushima K, Hirai Y, Koyama R, Wada S, Higashi A, et al. A novel myokine, secreted protein acidic and rich in cysteine (SPARC), suppresses colon tumorigenesis via regular exercise. Gut. 2013; 62:882-889.

36. Shvab A, Haase G, Ben-Shmuel A, Gavert N, Brabletz T, Dedhar S, Ben-Ze'ev A. Induction of the intestinal stem cell signature gene SMOC-2 is required for L1-mediated colon cancer progression. Oncogene. 2016; 35:549-557.

37. Brellier F, Ruggiero S, Zwolanek D, Martina E, Hess D, Brown-Luedi M, Hartmann U, Koch M, Merlo A, Lino M, Chiquet-Ehrismann R. SMOC1 is a tenascin-C interacting protein over-expressed in brain tumors. Matrix Biol. 2011; 30:225-233.

38. Fackler MJ, Umbricht CB, Williams D, Argani P, Cruz LA, Merino VF, Teo WW, Zhang Z, Huang P, Visvananthan K, Marks J, Ethier S, Gray JW, et al. Genome-wide methylation analysis identifies genes specific to breast cancer hormone receptor status and risk of recurrence. Cancer Res. 2011; 71:6195-6207.

39. Rex DK, Ahnen DJ, Baron JA, Batts KP, Burke CA, Burt RW, Goldblum JR, Guillem JG, Kahi CJ, Kalady MF, O’Brien MJ, Odze RD, Ogino S, et al. Serrated lesions of the colorectum: review and recommendations from an expert panel. Am J Gastroenterol. 2012; 107:1315-1329; quiz 1314, 1330.

40. Bettington M, Walker N, Rosty C, Brown I, Clouston A, McKeone D, Pearson SA, Klein K, Leggett B, Whitehall V. Serrated tubulovillous adenoma of the large intestine. Histopathology. 2016; 68:578-587.

41. Gonzalo DH, Lai KK, Shadrach B, Goldblum JR, Bennett AE, Downs-Kelly E, Liu X, Henricks W, Patil DT, Carver P, $\mathrm{Na}$ J, Gopalan B, Rybicki L, et al. Gene expression profiling of serrated polyps identifies annexin A10 as a marker of a sessile serrated adenoma/polyp. J Pathol. 2013; 230:420-429.

42. Suzuki H, Yamamoto E, Nojima M, Kai M, Yamano HO, Yoshikawa K, Kimura T, Kudo T, Harada E, Sugai T,
Takamaru H, Niinuma T, Maruyama R, et al. Methylationassociated silencing of microRNA-34b/c in gastric cancer and its involvement in an epigenetic field defect. Carcinogenesis. 2010; 31:2066-2073.

43. Toyota M, Suzuki H, Sasaki Y, Maruyama R, Imai K, Shinomura Y, Tokino T. Epigenetic silencing of microRNA$34 \mathrm{~b} / \mathrm{c}$ and B-cell translocation gene 4 is associated with $\mathrm{CpG}$ island methylation in colorectal cancer. Cancer Res. 2008; 68:4123-4132.

44. Kudo S, Tamura S, Nakajima T, Yamano H, Kusaka H, Watanabe H. Diagnosis of colorectal tumorous lesions by magnifying endoscopy. Gastrointest Endosc. 1996; 44:8-14.

45. Kudo S, Lambert R, Allen JI, Fujii H, Fujii T, Kashida H, Matsuda T, Mori M, Saito H, Shimoda T, Tanaka S, Watanabe H, Sung JJ, et al. Nonpolypoid neoplastic lesions of the colorectal mucosa. Gastrointest Endosc. 2008; 68:S3-47.

46. Kai M, Niinuma T, Kitajima H, Yamamoto E, Harada T, Aoki H, Maruyama R, Toyota M, Sasaki Y, Sugai T, Tokino T, Nakase H, Suzuki H. TET1 Depletion Induces Aberrant CpG Methylation in Colorectal Cancer Cells. PLoS One. 2016; 11:e0168281.

47. Keira Y, Takasawa A, Murata M, Nojima M, Takasawa K, Ogino J, Higashiura Y, Sasaki A, Kimura Y, Mizuguchi T, Tanaka S, Hirata K, Sawada N, et al. An immunohistochemical marker panel including claudin-18, maspin, and p53 improves diagnostic accuracy of bile duct neoplasms in surgical and presurgical biopsy specimens. Virchows Arch. 2015; 466:265-277.

48. Remmele W, Stegner HE. [Recommendation for uniform definition of an immunoreactive score (IRS) for immunohistochemical estrogen receptor detection (ER-ICA) in breast cancer tissue]. [Article in German]. Pathologe. 1987; 8:138-140.

49. Akimoto T, Takasawa A, Murata M, Kojima Y, Takasawa K, Nojima M, Aoyama T, Hiratsuka Y, Ono Y, Tanaka S, Osanai M, Hasegawa T, Saito T, et al. Analysis of the expression and localization of tight junction transmembrane proteins, claudin-1, $-4,-7$, occludin and JAM-A, in human cervical adenocarcinoma. Histol Histopathol. 2016; 31:921-931.

50. Kamimae S, Yamamoto E, Kai M, Niinuma T, Yamano HO, Nojima M, Yoshikawa K, Kimura T, Takagi R, Harada E, Harada T, Maruyama R, Sasaki Y, et al. Epigenetic silencing of NTSR1 is associated with lateral and noninvasive growth of colorectal tumors. Oncotarget. 2015; 6:29975-29990. http://doi.org/10.18632/oncotarget.5034. 